\title{
OPTIMAL SEVERANCE PAYMENT: THEORY AND PRACTICE
}

\section{Byeongju Jeong}
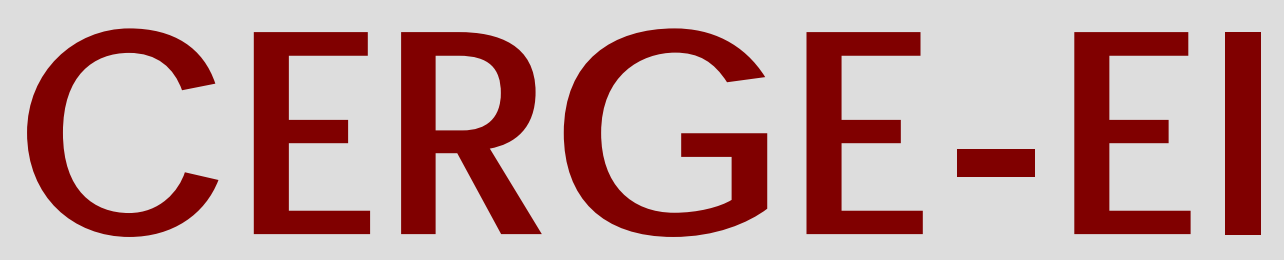

Charles University Centerfor Economic Research and Graduate Education Academy of Sciences of the Czech Republic Ec onomic Institute 


\title{
Working Paper Series 255 (ISSN 1211-3298)
}

\section{Optimal Severance Payment: Theory and Practice}

\author{
Byeongju Jeong
}

CERGE-EI

Prague, April 2005 
ISBN 80-7343-049-5 (Univerzita Karlova v Praze, CERGE)

ISBN 80-7344-038-5 (Národohospodářský ústav AV ČR, Praha) 


\title{
OPTIMAL SEVERANCE PAYMENT: THEORY AND PRACTICE
}

\author{
Byeongju Jeong* \\ CERGE-EI \\ POB 882, Politickych veznu 7 \\ 11121 Prague 1 \\ Czech Republic \\ byeongju.jeong@cerge-ei.cz
}

April 2005

\begin{abstract}
I present a model in which the employment contract includes severance payment as an instrument for achieving optimal separation between the firm and the worker. I show that the privately optimal severance payment from the model can replicate the level and the variation in actual severance payments (and notice periods) across OECD countries. I conduct a policy experiment in which the existing unemployment benefits are financed by a separation tax. Under this policy, the actual severance payments need to change only marginally in order to achieve socially optimal separation.
\end{abstract}

V článku prezentuji model, ve kterém pracovní smlouva používá odstupné jako nástroj, který má zajistit optimálnost propouštení zaměstanců. Zároveň ukazuji, že individuálně optimální platba odstupného plynoucí z mého modelu vede $\mathrm{k}$ velmi podobné variaci plateb odstupného a výpovědní lhůty, jakou pozorujeme v zemích OECD. Dále prezentuji výsledky experimentu, ve kterém existujíci podpora $\mathrm{v}$ nezaměstnanosti je financovaná pomocí daně $\mathrm{z}$ odstupného. V prrípade použití tohoto přístupu a pomocí malých změn v současných výplatách odstupného je možné dosáhnout společensky optimálního uspořádaní procesu propouštení ze zaměstnání.

\footnotetext{
* I thank the seminar participants at CERGE-EI, Kiel Workshop in Economics in Kiel, European Econometric Society Meeting in Lausanne, North American Econometric Society Meeting in Washington D.C., Michgan State University, Universitat Pompeau Fabra, and Universitat Autònoma de Barcelona for helpful comments.
} 


\section{Introduction}

I study severance payment as an instrument for achieving efficient separation between the firm and the worker. I present a model, calibrate it, and compare the actual and the optimal severance payments across countries. There are a number of previous related studies. Some view severance payment and other restrictions on separation as costs that hinder efficient turnovers. This view is implicit in Bentolila and Bertola (1990) and Hopenhayn and Rogerson (1993), for example. More recent studies have taken a sort of revisionist view. These include Pissarides (2000), Alvarez and Veracierto (2001), and Rogerson and Schindler (2002), all of which study the insurance role of severance payment. This paper shares their spirit, but explores an alternative rationale for severance payment that stems from the contractual environment.

In Section 2, I present a model that builds on Mortensen and Pissarides (1994). The innovation is that employment is a contractual relationship between the firm and the worker instead of a continuous bargaining relationship. A key result is that severance payment makes the firm internalize the welfare loss of the worker from separation, thereby achieving efficient separation. The welfare loss depends on, among other things, how responsive the contract wage is to the productivity shock: there are many optimal contracts in which severance payment inversely corresponds to wage responsiveness. I select one optimal contract, featuring a fixed wage and a fixed severance payment, under the assumption that the worker's productivity shock is unobservable to the worker or unverifiable in court. Thus, the rationale for severance payment stems purely from the contractual environment, not from the need for income insurance, even though its level depends on the welfare loss of the worker from separation. Another result is that an unemployment benefit financed by an employment tax creates a wedge between the private and the social valuation of separation. Consequently, the socially optimal severance payment is greater than the privately optimal one. 
In Section 3, I bring the model to the data. I present relevant labor market data for a cross section of OECD countries, and compute the effective severance payments that summarize the levels of severance payment and notice period. The calibration exercise shows that the privately optimal severance payment from the model is roughly able to generate the level and the variation of severance payments from the data, whereas the socially optimal payment is too large to be reconciled with the data. Based on the calibrated model, I conduct policy experiments with the objective of achieving socially optimal separation. The main experiment is switching from employment tax to a separation tax, which makes privately optimal separation coincide with the socially optimal one. With this tax change, holding unemployment benefits at the existing levels, the actual severance payments need to change only marginally in order to achieve socially optimal separation.

\section{The Model}

In this section, I present a model economy that builds on the search and matching model of Mortensen and Pissarides (1994). I characterize optimal severance payments in the presence of unemployment benefits financed by an employment tax.

\subsection{The Environment}

There are many workers whose number is normalized to 1. At the beginning of each period, a worker is either employed or unemployed. Employment is a match between a firm and a worker. A firm can employ only one worker. Thus there are as many matched firms as employed workers. A matched firm is either new or old, depending on whether the firm has produced in the previous period. A new firm receives a productivity, i.e., the output that will be obtained if it produces, drawn from the distribution function $F(y)$. An old firm receives a new productivity, drawn from $F(y)$, with probability $\lambda$; it maintains the previous period's productivity with probability $1-\lambda$. If a firm produces, it pays employment tax $\tau$ to the government, pays wage $w(y)$ to the worker, and keeps the residual $y-\tau-w(y)$. The 
firm survives into the next period with the current worker. If a firm does not produce, it pays severance payment $s(y)$ to the worker and the firm dies. Since the value of a vacant firm is zero in equilibrium, I could alternatively assume that the firm enters the matching market to recruit a new worker without any change in results.

A newly unemployed worker joins the pool of unemployed workers. An unemployed worker produces a fixed output $l$, and receives an unemployment benefit $b$ from the government. The output $l$ can be interpreted as leisure, return from home work, or return from working in the informal sector. The unemployed workers also search for new firms in a matching market. There is a free entry of firms, but each firm in the matching market must spend a search cost $c$ in each period. Let $u$ and $v$ denote the number of unemployed workers and the number of vacant firms. The number of new matches is given by the matching function $m(u, v)=A u^{\alpha} v^{1-\alpha}$, where $A$ is the matching productivity parameter and $\alpha$ the matching elasticity parameter. Finally, the government balances its budget by equating the expected tax revenue from the representative firm and the expected unemployment benefits that result from the separation of that firm and its worker.

Let $V_{0}$ denote the value of a vacant firm, and $V(y)$ the value of a matched firm after the productivity shock is realized. Let $\pi$ denote the job-finding rate: $\pi \equiv m(1, v / u)$. I have

$$
V_{0}=-c+\beta \pi \cdot \frac{u}{v} \cdot \int_{y} V(y) d F(y)=0
$$

and

$$
V(y)=g(y)\left\{y-\tau-w(y)+\beta \lambda \int_{y^{\prime}} V\left(y^{\prime}\right) d F\left(y^{\prime}\right)+\beta(1-\lambda) V(y)\right\}+(1-g(y))\{-s(y)\}
$$

where $\beta$ is a discount rate between 0 and 1 , and $g(y)$ denotes the production decision: it is equal to 1 if the firm produces and 0 if it does not. Similarly, let $W_{0}$ denote the 
expected utility of an unemployed worker, and $W(y)$ the expected utility of a worker after the productivity shock. I have

$$
W_{0}=l+b+\beta \pi \int_{y} W(y) d F(y)+\beta(1-\pi) \cdot W_{0}
$$

and

$$
W(y)=g(y)\left\{w(y)+\beta \lambda \int_{y^{\prime}} W\left(y^{\prime}\right) d F\left(y^{\prime}\right)+\beta(1-\lambda) W(y)\right\}+(1-g(y))\left\{s(y)+W_{0}\right\}
$$

Let $\phi$ denote the separation rate conditional on the output shock: $\phi \equiv \int_{y}(1-g(y)) d F(y)$. The law of motion for the number of unemployed workers is

$$
\pi u=\phi(\pi u+\lambda(1-u))
$$

From (1) to (4), I can derive the government budget constraint:

$$
\frac{b \phi}{1-\beta(1-\pi)}=\frac{\tau(1-\phi)}{1-\beta(1-\lambda)}
$$

The left-hand side is the expected discounted sum of unemployment benefits for an employed worker and the right-hand side is the expected discounted tax revenue generated from his employment (after a common multiplicative term has been canceled on both sides).

\subsection{Privately Optimal Severance Payment}

So far, I assumed the production decision $\{g(y)\}$, the wages $\{w(y)\}$, and the severance payments $\{s(y)\}$. Now consider employment as a contractual relationship between a worker and a firm, whereby the production decision is made by the firm and the worker receives a pre-specified wage or a severance payment depending on the firm's production decision. From (2), the firm's production decision is

$$
\begin{array}{ll}
g(y)=1 & \text { if } y-\tau-w(y)+\beta \lambda \int_{y^{\prime}} V\left(y^{\prime}\right) d F\left(y^{\prime}\right)+\beta(1-\lambda) V(y) \geq-s(y) \\
g(y)=0 & \text { if } y-\tau-w(y)+\beta \lambda \int_{y^{\prime}} V\left(y^{\prime}\right) d F\left(y^{\prime}\right)+\beta(1-\lambda) V(y)<-s(y)
\end{array}
$$


Abstracting from the bargaining process, simply assume that the firm and the worker choose a contract that maximizes the joint surplus and delivers $\rho$ share of the surplus to the worker:

$$
\{(w(y), s(y))\}=\arg \max \left\{\int_{y}(V(y)+W(y)) d F(y):(2),(4),(7), \text { and } W_{0} \text { given }\right\}
$$

and

$$
\rho \int_{y} V(y) d F(y)=(1-\rho) \int_{y}\left(W(y)-W_{0}\right) d F(y) .
$$

It will become clear that there exists such a contract. Given the unemployment benefit $b$, an endogenous-severance-payment equilibrium is the wage schedule $\{w(y)\}$, the severance payment schedule $\{s(y)\}$, the firm values $V_{0}$ and $\{V(y)\}$, the worker's utilities $W_{0}$ and $\{W(y)\}$, the production rule $\{g(y)\}$, the number of unemployed workers $u$, the number of vacant firms $v$, and the employment $\operatorname{tax} \tau$, which together satisfy (1) to (9).

From (2) and (4), observe that the joint-surplus maximizing production rule is $g(y)=1$ if $y-\tau+\beta \lambda \int\left(V\left(y^{\prime}\right)+W\left(y^{\prime}\right)\right) d F\left(y^{\prime}\right)+\beta(1-\lambda)(V(y)+W(y)) \geq W_{0}$ and $g(y)=0$ otherwise. Let $\bar{y}$ denote the cut-off output: $\bar{y} \equiv W_{0}+\tau-\beta \int\left(V\left(y^{\prime}\right)+W\left(y^{\prime}\right) d F\left(y^{\prime}\right)-\beta(1-\lambda)(V(y)+\right.$ $W(y))$. Further, assume that $w(y)$ and $s(y)$ are continuous everywhere. For the firm to choose the joint-surplus maximizing production rule, from (7) I have

$$
w(\bar{y})+\beta \lambda \int_{y} W(y) d F(y)+\beta(1-\lambda) W(\bar{y})=s(\bar{y})+W_{0} \quad \text { if } y=\bar{y}
$$

and

$$
\begin{aligned}
& w(y)-w(\bar{y}) \leq s(y)-s(\bar{y})+y-\bar{y} \quad \text { if } y \geq \bar{y} \\
& w(y)-w(\bar{y})>s(y)-s(\bar{y})+y-\bar{y} \quad \text { if } y<\bar{y} .
\end{aligned}
$$

The conditions (10) and (11) are necessary and sufficient for the contract to maximize the joint surplus.

Observe that there are an infinite variety of privately optimal contracts. One such contract, which I will call the flexible-wage contract, is to provide no severance payment and to divide any incremental output by the shares $\rho$ and $1-\rho$ between the worker and the 
firm: $s(y)=0$ for all $y ; w(y)-w(\bar{y})=\rho(y-\bar{y})$ for all $y$; and $w(\bar{y})+\beta \lambda \int W(y) d F(y)+\beta(1-$ ג) $W(\bar{y})=W_{0}$. Under this contract, the outcome is the same as if there was bargaining between the worker and the firm in each period, as in Mortensen and Pissarides (1994). An alternative contract, which I will call the fixed-wage contract, is to provide a fixed wage and a fixed severance payment: $s(y)=\bar{s}$ for all $y ; w(y)=\bar{w}$ for all $y$; and $\bar{w}+$ $\beta \lambda \int W(y) d F(y)+\beta(1-\lambda) W(\bar{y})=\bar{s}+W_{0}$. From (3) and (4), I can derive

$$
\bar{s}=\frac{\bar{w}-l-b}{1-\beta(1-\pi)} .
$$

Note that the severance payment exactly compensates for the welfare loss from becoming unemployed. Thus the worker's utility is the same under all $y$ and the output shock is entirely absorbed by the firm. These two contracts are two extremes, and there are a variety of privately optimal contracts where the wage is neither fully flexible nor fully fixed.

The selection among the optimal contracts would depend on the contractual environment, about which little has been said so far. Now suppose that the productivity shock is unobservable to the worker, following Grossman and Hart (1983), among others. The incentive-compatible contract wage and severance payment would then have to be independent of the shock since otherwise the firm would always claim a low productivity shock. The fixed-wage contract would then emerge as the unique optimal contract. The same result follows if the productivity shock is not verifiable in court. Based on these considerations, I assume the fixed-wage contract for the rest of the paper. I underline this assumption since the flexible-wage contract could outperform the fixed-wage contract in an alternative contractual environment, e.g., one with high enforcement costs.

\subsection{Socially Optimal Severance Payment}

There are potentially two sources of inefficiency in the current model: matching and separation. Efficient matching requires the matching elasticity $\alpha$ to be equal to the surplus 
share $\rho$ in the absence of unemployment benefits (Hosios 1990). Unemployment benefits strengthen the bargaining position of the worker and thereby improve efficiency if $\rho<\alpha$, and vice-versa. I do not mean that this is any serious rationale for unemployment benefits: the current model studies the impact of, not the cause for, unemployment benefits. In this spirit, consider the problem of choosing a severance payment that leads to socially optimal separation, taking unemployment benefit $b$ as given. Let $\tilde{s}$ denote a government-mandated severance payment. For this payment to be binding, the firm-worker must not have a means of undoing its intended effect (Lazear 1990). In the current model, it is sufficient that the employment contract specifies a fixed wage, call it $\tilde{w}$, taking $\tilde{s}$ as given: for all $y$, $s(y)=\tilde{s}$ and

$$
w(y)=\tilde{w}=\arg \max \left\{\int_{y}(V(y)+W(y)) d F(y):(2),(4),(7), \text { and } W_{0} \text { given }\right\}
$$

This is an assumption mainly for an expositional purpose: the relevance and the implementability of the socially optimal severance payment will be examined in Section 3. Given the unemployment benefit $b$ and the severance payment $\tilde{s}$, an exogenous-severance-payment equilibrium is the wage $\tilde{w}$, the firm values $V_{0}$ and $\{V(y)\}$, the worker's utilities $W_{0}$ and $\{W(y)\}$, the production rule $\{g(y)\}$, the number of unemployed workers $u$, the number of vacant firms $v$, and the employment tax $\tau$, which together satisfy (1) to (7), (8)', and (9).

I consider the socially optimal severance payment as the one that leads to the maximum present value of aggregate outputs net of vacancy costs in equilibrium, ignoring any transitional and distributional issues. ${ }^{1}$ Let $Y_{0}$ denote the discounted expected output net of vacancy costs associated with an unemployed worker, and $Y(y)$ that associated with an employed worker with current output $y$ :

$$
Y_{0}=l-c \cdot \frac{v}{u}+\beta \pi \int_{y} Y(y) d F(y)+\beta(1-\pi) \cdot Y_{0}
$$

\footnotetext{
1 An equilibrium as defined above is implicitly a steady-state, which leaves open transitional issues. A transition would feature a redistribution of outputs among the firms, the employed workers, and the unemployed workers.
} 
and

$$
Y(y)=g(y)\left\{y+\beta \lambda \int_{y^{\prime}} Y\left(y^{\prime}\right) d F\left(y^{\prime}\right)+\beta(1-\lambda) Y(y)\right\}+(1-g(y)) \cdot Y_{0} .
$$

Comparing (13) and (14) with (1) to (4), (8)', and (9), I can show that, holding $\{g(y)\}$, $\int_{y} Y(y) d F(y)=\int_{y} V(y) d F(y)+\int_{y} W(y) d F(y)$ and $Y_{0}=W_{0}-b /(1-\beta(1-\pi))$ so that the free entry condition in (1) can be rewritten as

$$
c=\beta \pi \cdot \frac{u}{v} \cdot(1-\rho)\left\{\int_{y} Y(y) d F(y)-Y_{0}-\frac{b}{1-\beta(1-\pi)}\right\} .
$$

Given a production rule $\{g(y)\}$, I can find $Y_{0}$ and $\{Y(y)\}$ from (13), (14), and (15). The present value of aggregate outputs is the sum of $Y^{\prime}$ 's weighted by the shares of workers across employment status and current productivity. However, the shares of workers are not relevant in finding the socially optimal production rule: I can show that each and every $Y$ (i.e., $Y_{0}$ and $Y(y)$ for all $y$ ) is maximized by the production rule, $g(y)=1$ if $y+\beta \lambda \int Y\left(y^{\prime}\right) d F\left(y^{\prime}\right)+\beta(1-\lambda) Y(y) \geq Y_{0}$ and $g(y)=0$ otherwise.

For the firm to choose the socially optimal production rule, from (3), (4), (6), and (7), I can derive that the severance payment must be given by

$$
\tilde{s}=\frac{\tilde{w}+\tau-l}{1-\beta(1-\pi)}
$$

In comparison to (12), the unemployment benefit $b$ is missing and the $\operatorname{tax} \tau$ is added. Intuitively, the social welfare loss from becoming unemployed includes taxes that represent a portion of output that accrue to employment, and it is unaffected by unemployment benefits since they do not represent an output that accrue to unemployment. Thus the socially optimal severance payment is greater than the privately optimal one, holding the wage and the job-finding rate. As a corollary, the worker would make a net gain from becoming unemployed under the socially optimal severance payment. This is a discomforting result, and will be revisited in Section 3 . 


\section{Quantitative Exercise}

In this section, I conduct a calibration exercise, and examine the relevance of the optimal severance payments from the model in a cross section of OECD data. I conduct policy experiments, and assess how socially optimal separation can be achieved.

\subsection{Labor Market Data}

Table 1 presents the levels of severance payments and advance notice periods for 24 OECD countries. The data are from the OECD Employment Outlook (1999) and cover the late 1990's. They are mainly based on the legal regulation, and are average values across worker types. The motivation for looking at the notice period is that it works as a significant restriction on separation like severance payment does. Imagine that the firm effectively fires the worker when the notice period begins and pays wages during the period as a severance payment; being effectively unemployed, the worker searches for a new job during the notice period.

Table 1 also presents unemployment rates, unemployment duration, and replacement rates for the same countries. Unemployment rates and duration were constructed based on the OECD Labour Force Statistics (2002) and cover the years from 1992 to 2001. The unemployment rates are the averages over the period. The Labor Force Statistics provide the percentage of the unemployed who have been unemployed for one month or less for all countries except for Korea, Poland, and Turkey, for which the three-month figures are provided. I averaged the percentages over the ten year period (less than that for some depending on the availability of data). The unemployment duration in months for a country is the reciprocal of the average percentage for each country (multiplied by three for the three countries mentioned above). The replacement rates are from the OECD Benefits and Wages (2002), and are for the year 1999. I report the summary measure: it measures the ratio of the after-tax benefit and the after-tax previous wage of the unemployed worker, 
averaged over five years of unemployment and over different types of workers. The data were not available for Turkey and Mexico.

\subsection{Adjusting the Data}

In the data, there are three different levels of severance payment and lengths of notice period depending on employment duration. For each country, I fix the levels as follows. I estimate the expected employment duration as $e_{d}=\left(1-u_{d}\right) /\left(\pi_{d} \cdot u_{d}\right)$, where $u_{d}$ denotes the unemployment rate in the data and $\pi_{d}$ the job-finding rate, computed as the reciprocal of unemployment duration in the data. The estimate ranges from 45 months for the United States to 333 months for the Netherlands. Let $s_{4}$ denote the severance payment for 4 years (48 months) of employment in the data and $s_{20}$ that for 20 years (240 months) of employment. The fixed severance payment is a weighted average: $s_{f}=s_{4} \cdot\left(240-e_{d}\right) / 192+$ $s_{20} \cdot\left(e_{d}-48\right) / 192$. Similarly, the fixed notice period is $n_{f}=n_{4} \cdot\left(240-e_{d}\right) / 192+n_{20}$. $\left(e_{d}-48\right) / 192$.

As discussed above, the notice period effectively adds to unemployment and severance payment. I adjust the data in order to account for this. The first column of Table 2, the effective unemployment rate, presents the official rates from Table 1 plus the estimated fractions of the work force under the notice period:

$$
u_{e}=\frac{u_{d}}{\left(1-\pi_{d}\right)^{n_{f}}}
$$

Since unemployed workers in reality do not receive unemployment benefits during the notice period, I adjust downward the benefits in the data so that if the adjusted level were applied to an unemployed worker throughout his effective unemployment duration, the expected discounted sum of his unemployment benefits would be equal to that under the actual sequence of benefits. Let $b_{d}$ denote the replacement rate in the data. The effective replacement rate or, equivalently, the effective monthly unemployment benefit in units of monthly wage is

$$
b_{e}=b_{d} \beta^{n_{f}}\left(1-\pi_{d}\right)^{n_{f}} .
$$


I set the discount rate $\beta=.9966$, which implies an annual interest rate of about $4 \%$. The second column of Table 2 presents the results. I make a similar adjustment to severance payment. Let $s_{d}$ denote the severance payment in units of monthly wage in the data. The effective severance payment in units of monthly wage is

$$
s_{e}=s_{f} \beta^{n_{f}}\left(1-\pi_{d}\right)^{n_{f}}+\frac{1-\beta^{n_{f}}\left(1-\pi_{d}\right)^{n_{f}}}{1-\beta\left(1-\pi_{d}\right)} .
$$

The first term is the expected severance payment discounted to the period when the notice period starts. The second term is the expected wages during the notice period. The third column of Table 2, the effective severance payment, presents the results.

\subsection{Calibration}

I calibrate the model in Section 2 for each country. At the outset, I leave open whether the effective severance payment from the data should resemble either of the optimal severance payments in the model. ${ }^{2}$ Instead, I let the calibration exercise guide me on the relevance of the optimal severance payments in the model. Formally, I calibrate the model so that, given the effective unemployment benefit $b_{e}$ and the effective severance payment $s_{e}$, the exogenous-severance-payment equilibrium defined in Section 2.3 replicates the effective unemployment rate $u_{e}$ and the job-finding rate $\pi_{d}$. As mentioned, I set $\beta=.9966$. I assume that the output distribution function is normal: $F(y) \sim N(\mu, \sigma)$. I set the output shock frequency $\lambda=.083$, which implies that a new shock arrives about once a year. This is not based on any data, but the main results are not sensitive to $\lambda$. I make the common assumption that the matching elasticity $\alpha=.5$ and the bargaining parameter $\rho=.5$. I assume that the firm's search $\operatorname{cost} c=.2 \mu$, which is (a version of) a common specification. Similarly, I assume that the home output is a constant fraction of the mean output at work: $l=\theta \mu$. Given a value of $\theta$, I choose the values of the output mean $\mu$, the output

\footnotetext{
2 It is easy to imagine that the actual severance payment is determined by factors absent in the current model, e.g., unions, voters. As mentioned, this is an implicit assumption in some of the earlier studies such as Bentolila and Bertola (1990) and Hopenhayn and Rogerson (1993). It is an explicit assumption in Saint-Paul (2000).
} 
standard deviation $\sigma$, and the matching productivity parameter $A$ so that in equilibrium the unemployment rate is $u_{e}$, the job-finding rate is $\pi_{d}$, and the wage $\tilde{w}$ is (normalized to) 1.

It remains to calibrate $\theta$, which has a large impact on the quantitative results. Without an obvious way of fixing its value, I work with a range of values. The fourth column of Table 2 presents the private welfare loss from unemployment, that is, the value of the right-hand side of (12) in equilibrium, when $\theta=.2$. Observe that the welfare loss and the effective severance payment are fairly correlated across countries, and the two are comparable on average. Thus, if $\theta=.2$, the effective severance payments from the data roughly resemble the privately optimal severance payments from the model. The fourth column also reports a range of private welfare loss in brackets. The first number in the range corresponds to $\theta=.4$, the second number to $\theta=.0$. If $\theta>.4$, the welfare loss from unemployment turns negative (i.e., the sum of home output and unemployment benefit exceeds the wage) and, consequently, the equilibrium does not exist for many countries. For the Netherlands, this is the case even if $\theta=.4$. The fifth column of Table 3 presents the social welfare loss from unemployment, that is, the value of the right-hand side of (16) in equilibrium for the same values of $\theta$. Observe that the social welfare loss is much larger than the effective severance payment for nearly all countries and values of $\theta$. In other words, the socially optimal severance payments from the model are too large to be reconciled with the data. In summary, the privately optimal severance payments in the model, under reasonable parameter values, come close to the effective severance payments from the data, whereas the socially optimal severance payments do not.

\subsection{Policy Experiments}

Having calibrated the model, I calculate optimal severance payments under various assumptions. First, consider a policy that allows severance payment to be privately set, 
while maintaining the existing level of unemployment benefit $b_{e} \cdot{ }^{3}$ The economy would then adjust to the endogenous-severance-payment equilibrium in Section 2.2 under which (12) holds. The first column of Table 3 presents the privately optimal severance payments, after calculating the new equilibrium. The payments are in units of initial monthly wage (see Footnote 3 ). Throughout the table, the main number corresponds to $\theta=.2$, the first number in the bracket to $\theta=.4$, and the second number in the bracket to $\theta=.0$, repeating the convention in Table 2. Many equilibria do not exist. ${ }^{4}$ If the equilibrium exists, the new severance payment is not so different from the initial payment (Table 2, third column), and is nearly the same as the initial welfare loss from unemployment (Table 2, fourth column). Since the initial payments were not far from the initial private welfare loss, the required adjustments are modest.

Next, consider a policy that enforces the socially optimal severance payment, again maintaining the existing level of unemployment benefit $b_{e}$. The economy would then adjust to a new exgogenous-severance-payment equilibrium under which (16) holds. The second column of Table 3 presents the socially optimal severance payments, after calculating the new equilibrium. The severance payments increase dramatically from the initial levels (Table 2, third column), but fall somewhat short of the initial social welfare loss (Table 2, fifth column). The shortfall reflects the overall impact of several changes. The rise in severance payment lowers the separation rate, and thereby lowers the tax rate. The efficiency improvement in separation raises the incentive for firm entry, increasing the jobfinding rate. The wage changes little: the efficiency improvement in separation allows for

\footnotetext{
3 That is, the absolute level of unemployment benefit, equivalently the benefit in units of initial monthly wage, is maintained. In all policy experiments, the wages change in the order of a few percent at most, so the benefit in units of new equilibrium wage is approximately constant as well.

4 They are mainly for high values of $\theta$, which imply that the severance payment has to fall from the initial level. Intuitively, a fall in severance payment raises the separation rate, which requires a hike in the employment tax rate, leading to a further rise in the separation rate and so on. In other words, the given unemployment benefit $b_{e}$ is unsustainable under some parameter values.
} 
a higher wage while the rise in severance payment lowers the wage in order to maintain the worker's share of joint surplus.

As alluded to in Section 2, the large gap between the socially optimal severance payments (Table 3, second column) and the private welfare loss from unemployment under those payments (Table 3 , thrid column $)^{5}$ raises the issue of whether and how the latter can be implemented: the worker-firm has a high incentive to find means of circumventing the socially optimal payments, all the more so since the worker would make a large net gain from becoming unemployed. This motivates consideration of an alternative tax/benefit policy that reconciles the difference between the privately, and the socially, optimal severance payments. One such policy is to eliminate the employment tax (i.e, $\tau=0$ ) and to fund the benefits by a severance tax instead. Thus I can rewrite (2):

$$
V(y)=g(y)\left\{y-w(y)+\beta \lambda \int_{y^{\prime}} V\left(y^{\prime}\right) d F\left(y^{\prime}\right)+\beta(1-\lambda) V(y)\right\}+(1-g(y))\{-s(y)-\check{\tau}\}
$$

where $\check{\tau}$ is the severance tax. As before, the government balances the budget by equating the expected tax revenue from the representative firm and the expected unemployment benefits that result from that firm's separation decision. From (1), (2)', (3), and (4), I have

$$
\check{\tau}=\frac{b}{1-\beta(1-\pi)} .
$$

Thus each tax payment pays for the (expected) unemployment benefits for the worker who has become unemployed on the occasion.

Following the same reasoning as in Section 2, I can show that under the severance tax policy the privately and socially optimal severance payment is $\check{s}=(\check{w}-l-b) /(1-$ $\beta(1-\pi)$ ), equivalent to $(12)$, where $\check{w}$ denotes the new equilibrium wage. Intuitively, the separation tax makes the firm internalize the social costs of providing unemployment

\footnotetext{
5 As will be shown shortly, the private welfare loss under socially optimal severance payment is equivalent to the optimal severance payment under a separation tax (Table 3, third column), which is nearly the same as the initial private welfare loss (Table 2, fourth column).
} 
benefits. Therefore, the privately optimal severance payment under this policy achieves the same outcome as the socially optimal severance payment under the employment tax policy, except for the (superficial) difference that the worker receives what would be employment taxes as additional wages in exchange for the reduction in the severance payment in the amount of the separation tax: $\check{w}=\tilde{w}+\tau$ and $\check{s}=\tilde{s}-\check{\tau}$. As a result, there is no net gain from becoming unemployed. The third column of Table 3 presents optimal severance payments under the separation tax policy, again maintaining the unemployment benefit $b_{e}$. They nearly replicate the privately optimal severance payments under the employment tax policy (Table 3, first column), which were not far from the initial severance payments (Table 2, third column) and were nearly the same as the initial welfare loss from unemployment (Table 2, fourth column). This somewhat hides two offsetting general equilibrium effects. The efficiency improvement in separation allows for a higher wage. At the same time, it raises the incentive for firm entry, increasing the job-finding rate.

Up to now, I have fixed the unemployment benefit at the effective level $b_{e}$ from the data, and studied its impact on the optimal severance payment. As mentioned, the model in this paper does not provide a (serious) rationale for unemployment benefits. Nonetheless, within the model the optimal level of unemployment benefits depends on the matching elasticity $\alpha$ and the surplus share $\rho$. In calibrating the model, I made the common assumption that $\alpha=\rho$, in which case zero unemployment benefit is optimal. ${ }^{6}$ With this motivation, consider the policy of eliminating taxes and benefits all together: $\tau=b=0$. Comparing (12) and (16), observe that the privately optimal severance payment coincides with the socially optimal one under this policy. The fourth column of Table 3 presents the optimal payments after calculating the new equilibrium under this policy. They are larger than the privately optimal severance payments under the employment tax policy (Table

${ }^{6}$ To be precise, in the problem of output maximization in Section 2.3, each and every $Y$ (i.e., $Y_{0}$ and $Y(y)$ for all $y)$ is maximized when the unemployment benefit $b$ is zero and the severance payment is given by (16). 
3 , first column) but smaller than the socially optimal severance payments under the same policy (Table 3, second column). Eliminating unemployment benefits directly raises the private welfare loss. The efficiency improvement in matching and separation raises wages somewhat but, more significantly, raises the job-finding rate, lowering the welfare loss.

\section{Conclusion}

I highlight two main results. First, the employment contract features severance payment as a means of achieving (privately) optimal separation under asymmetric information between the firm and the worker. The privately optimal severance payment, under reasonable parameter values, closely mimics the average of and the variation in actual severance payments (and notice periods) across the OECD countries. Second, under the presence of unemployment benefits, the privately optimal severance payment achieves socially optimal separation if the funding source switches from the employment tax to a separation tax. Switching the tax regime while maintaining the existing unemployment benefits makes little change in the privately optimal severance payment, so socially optimal separation requires only marginal changes in actual severance payments.

I also note some shortcomings and limitations. First, I assumed asymmetric information between the firm and the worker in order to select among the optimal contracts, but not with the conviction that this is necessarily the dominant aspect of the actual contractual environment. For example, I am not sure what would be the optimal contract if there is a degree of asymmetric information combined with an enforcement cost. Second, I included the notice period in calculating the summary measure of severance payment. Doing so, I effectively assumed that the notice period is a perfect substitute for severance payment. The rationale for the notice period and its impact on the labor market could be different from that for severance payment. Third, social optimum was defined in terms of maximizing the discounted sum of outputs net of vacancy costs in the steady state 
of the economy. This could be refined by incorporating distributional and transitional constraints. I leave these issues for future research. 


\section{REFERENCES}

Alvarez, F. and Veracierto, M. (2001), "Severance Payments in an Economy with Frictions," Journal of Monetary Economics 47:477-98.

Bentolila, S. and Bertola, G. (1990), "Firing Costs and Labour Demand: How Bad is Eurosclerosis?," Review of Economics Studies 57:381-402.

Hosios, A. (1990), "On the Efficiency of Matching and Related Models of Search and Unemployment," Review of Economic Studies 57:279-98.

Grossman, S. and Hart, O. (1983), "Implicit Contracts under Asymmetric Information," The Quarterly Journal of Economics 98:123-56.

Hopenhayn, H. and Rogerson, R. (1993), "Job Turnover and Policy Evaluation: A General Equilibrium Analysis," Journal of Political Economy 101:915-38.

Lazear, E. (1990), "Job Security Provisions and Employment," Quarterly Journal of Economics 105:699-726.

Mortensen, D., and Pissarides, C. (1994), "Job Creation and Job Destruction in the Theory of Unemployment," Review of Economic Studies, 61:397-415.

Pissarides, C. (2001), "Employment Protection," Labor Economics 8:131-59.

Rogerson, R., and Schindler, M. (2002), "The Welfare Costs of Worker Displacement," Journal of Monetary Economics 49:1213-34.

OECD (1999), Employment Outlook, Chapter 2, "Employment Protection and Labour Market Performance," OECD, Paris.

OECD (2002), Labour Force Statistics 1981-2001, OECD, Paris.

OECD (2002), Benefits and Wages, OECD, Paris.

Saint-Paul, G. (2000), The Political Economy of Labour Market Institutions, Oxford University Press. 
Table 1: Labor Market Data

\begin{tabular}{|c|c|c|c|c|c|c|c|c|c|}
\hline Country & $\begin{array}{r}\text { Severanc } \\
\text { aft } \\
9 \text { months }\end{array}$ & $\begin{array}{l}\text { Pay. in } \\
\text { working } \\
4 \text { years }\end{array}$ & $\begin{array}{l}\text { on. wage } \\
\text { for: } \\
20 \text { years }\end{array}$ & $\begin{array}{r}\text { Notice } \\
\text { aft } \\
9 \text { months }\end{array}$ & $\begin{array}{l}\text { Period in } \\
\text { working } \\
4 \text { years }\end{array}$ & $\begin{array}{l}\text { רonths } \\
\text { or: } \\
20 \text { years }\end{array}$ & $\begin{array}{l}\text { Unemp. } \\
\text { Rate } \\
\text { in percent }\end{array}$ & $\begin{array}{l}\text { Unemp. } \\
\text { Duration } \\
\text { in months }\end{array}$ & $\begin{array}{c}\text { Replace. } \\
\text { Rate } \\
\text { in percent }\end{array}$ \\
\hline Belgium & .0 & .0 & .0 & 2.0 & 2.8 & 9.0 & 11.7 & 11.6 & 70 \\
\hline France & .0 & .4 & 2.7 & 1.0 & 2.0 & 2.0 & 11.2 & 22.8 & 52 \\
\hline Germany & .0 & .0 & .0 & 1.0 & 1.0 & 7.0 & 8.4 & 12.2 & 63 \\
\hline Ireland & .0 & .2 & 2.2 & .3 & .5 & 2.0 & 10.2 & 18.2 & 55 \\
\hline Netherland & .0 & .0 & .0 & 1.0 & 1.0 & 3.0 & 5.3 & 18.6 & 76 \\
\hline Switzerland & .0 & .0 & 2.0 & 1.0 & 2.0 & 3.0 & 3.4 & 8.1 & 83 \\
\hline United Kingdom & .0 & .5 & 2.4 & .2 & .9 & 2.8 & 7.6 & 7.9 & 69 \\
\hline Greece & .3 & 1.0 & 5.8 & .5 & 1.5 & 8.0 & 10.3 & 18.6 & 17 \\
\hline Italy & .7 & 3.5 & 18.0 & .3 & 1.1 & 2.2 & 11.2 & 21.7 & 13 \\
\hline Portugal & 3.0 & 4.0 & 20.0 & 2.0 & 2.0 & 2.0 & 5.5 & 10.6 & 62 \\
\hline Spain & .5 & 2.6 & 12.0 & 1.0 & 1.0 & 1.0 & 19.1 & 24.9 & 50 \\
\hline Turkey & .0 & 4.0 & 20.0 & 1.0 & 2.0 & 2.0 & 7.8 & 14.8 & - \\
\hline Denmark & .0 & .0 & 1.5 & 1.8 & 3.0 & 4.3 & 6.9 & 4.2 & 81 \\
\hline Finland & .0 & .0 & .0 & 1.0 & 2.0 & 6.0 & 12.8 & 7.2 & 69 \\
\hline Sweden & .0 & .0 & .0 & 1.0 & 3.0 & 6.0 & 8.1 & 5.6 & 79 \\
\hline Czech Republic & 1.0 & 1.0 & 1.0 & 2.0 & 2.5 & 2.5 & 5.7 & 9.8 & 72 \\
\hline Hungary & .0 & 1.0 & 5.0 & 1.0 & 1.2 & 3.0 & 9.0 & 13.5 & 42 \\
\hline Poland & .0 & .0 & .0 & 1.0 & 3.0 & 3.0 & 13.7 & 14.7 & 60 \\
\hline Canada & .0 & .2 & 1.3 & .5 & .5 & .5 & 9.1 & 4.7 & 54 \\
\hline Mexico & 3.0 & 3.0 & 3.0 & .0 & .0 & .0 & 3.2 & 3.1 & - \\
\hline United States & .0 & .0 & .0 & .0 & .0 & .0 & 5.3 & 2.6 & 32 \\
\hline Australia & .0 & 1.0 & 1.0 & .2 & .7 & 1.2 & 8.3 & 6.3 & 49 \\
\hline Japan & .0 & 1.5 & 4.0 & 1.0 & 1.0 & 1.0 & 3.6 & 6.1 & 64 \\
\hline Korea & .0 & 2.0 & 6.0 & 1.0 & 1.0 & 1.0 & 3.5 & 5.3 & 20 \\
\hline Average & .4 & 1.1 & 4.5 & .9 & 1.5 & 3.0 & 8.4 & 11.4 & 56 \\
\hline
\end{tabular}


Table 2: Qantitative Exercise - Calibration

\begin{tabular}{|c|c|c|c|c|c|}
\hline Country & $\begin{array}{l}\text { Effective } \\
\text { Unemp. R. } \\
\text { in percent }\end{array}$ & $\begin{array}{c}\text { Effective } \\
\text { Replace. R. } \\
\text { in percent }\end{array}$ & $\begin{array}{c}\text { Effective } \\
\text { Sever. Pay. } \\
\text { in mon. wage }\end{array}$ & $\begin{array}{c}\text { Private } \\
\text { Welfare Loss } \\
\text { in mon. wage }\end{array}$ & $\begin{array}{c}\text { Social } \\
\text { Welfare Loss } \\
\text { in mon. wage }\end{array}$ \\
\hline Belgium & 16.9 & 48 & 3.6 & $3.5(1.3-5.9)$ & $10.0(7.6-12.3)$ \\
\hline France & 12.3 & 47 & 3.8 & $6.7(2.4-11.2)$ & $18.1(13.6-22.6)$ \\
\hline Germany & 11.5 & 46 & 3.3 & $4.0(1.6-6.4)$ & $10.0(7.5-12.5)$ \\
\hline Ireland & 11.0 & 51 & 2.6 & $4.8(1.4-8.5)$ & $14.6(11.0-18.2)$ \\
\hline Netherland & 6.6 & 60 & 3.6 & 3.3 (NA-7.0) & 14.6 (NA-18.3) \\
\hline Switzerland & 5.0 & 56 & 3.9 & $1.9(0.3-3.5)$ & $6.5(4.9-8.1)$ \\
\hline United Kingdom & 9.2 & 57 & 2.2 & $1.7(0.2-3.3)$ & $6.6(5.0-8.2)$ \\
\hline Greece & 13.9 & 12 & 7.5 & $11.8(8.6-15.4)$ & $14.4(10.8-17.9)$ \\
\hline Italy & 12.2 & 12 & 13.5 & $13.8(9.9-17.9)$ & $16.5(12.4-20.6)$ \\
\hline Portugal & 6.7 & 51 & 14.3 & $3.0(0.9-5.1)$ & $8.6(6.5-10.7)$ \\
\hline Spain & 19.9 & 48 & 6.2 & $7.0(2.5-12.0)$ & $20.7(15.6-25.7)$ \\
\hline Turkey & 8.9 & - & 14.5 & - & - \\
\hline Denmark & 15.7 & 35 & 2.4 & $1.9(1.1-2.7)$ & $3.7(2.9-4.5)$ \\
\hline Finland & 17.3 & 51 & 1.9 & $2.0(0.6-3.5)$ & $6.3(4.8--7.8)$ \\
\hline Sweden & 15.3 & 41 & 2.6 & $2.1(1.0-3.2)$ & $4.8(3.7-5.9)$ \\
\hline Czech Republic & 7.5 & 55 & 3.1 & $2.3(0.5-4.3)$ & $8.0(6.0-9.9)$ \\
\hline Hungary & 10.5 & 36 & 4.4 & $5.7(3.1-8.3)$ & $10.8(8.1-13.5)$ \\
\hline Poland & 16.9 & 48 & 2.8 & $4.3(1.5-7.3)$ & $12.4(9.3-15.4)$ \\
\hline Canada & 10.3 & 48 & 0.7 & $1.5(0.5-2.4)$ & $3.9(3.0-4.9)$ \\
\hline Mexico & 3.2 & - & 3.0 & & \\
\hline United States & 5.4 & 32 & 0.0 & $1.2(0.7-1.7)$ & $2.1(1.6-2.6)$ \\
\hline Australia & 9.5 & 43 & 1.6 & $2.3(1.0-3.5)$ & $5.2(3.9-6.4)$ \\
\hline Japan & 4.3 & 53 & 3.5 & $1.6(0.4-2.8)$ & $5.0(3.7-6.2)$ \\
\hline Korea & 4.3 & 16 & 4.3 & $3.4(2.3-4.4)$ & $4.2(3.2-5.3)$ \\
\hline Average & 10.6 & 43 & 4.2 & $4.1(2.0-6.4)$ & $9.4(6.9-11.7)$ \\
\hline
\end{tabular}


Table 3: Qantitative Exercise - Optimal Severance Payment

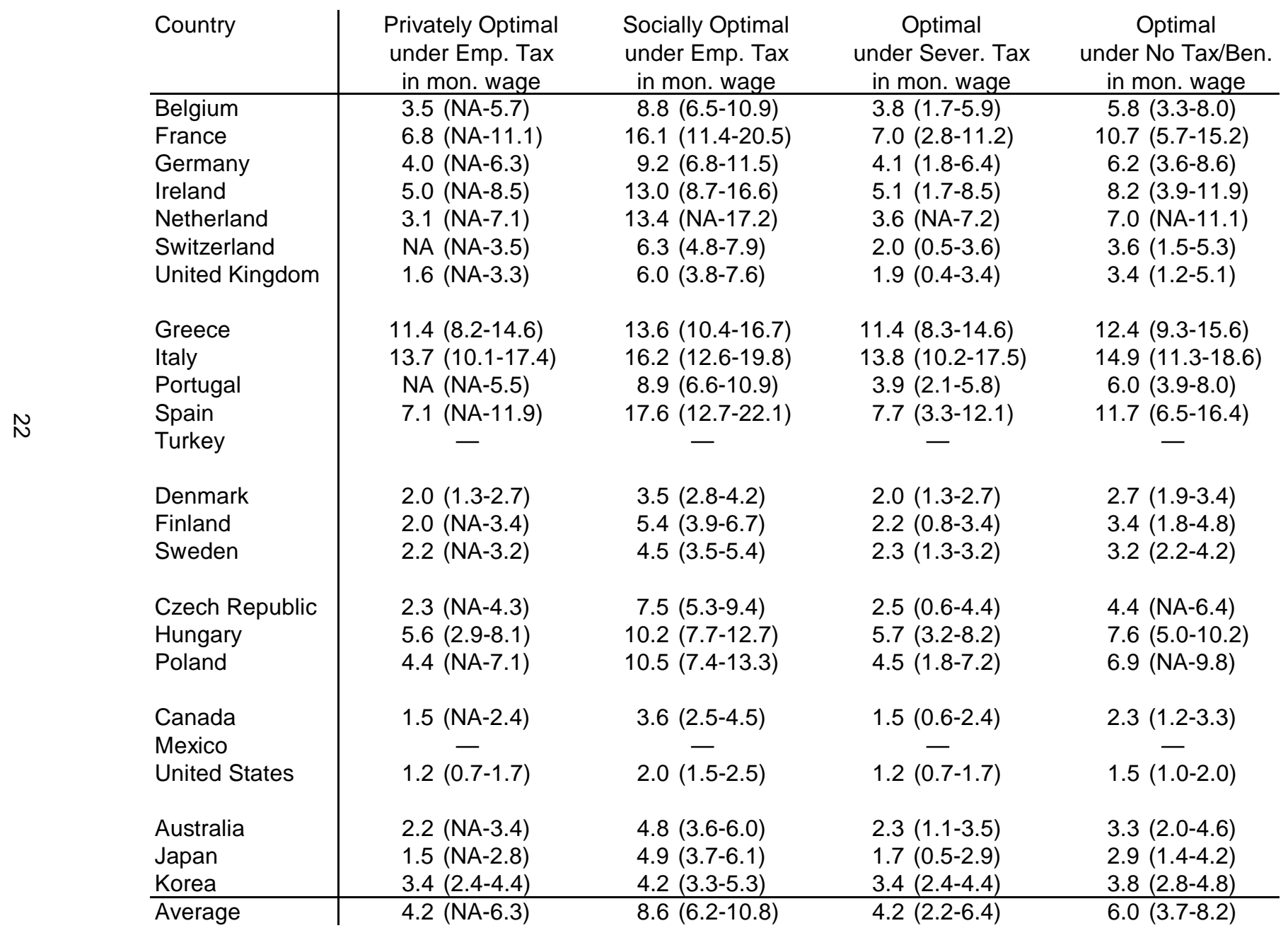


Individual researchers, as well as the on-line and printed versions of the CERGE-EI Working Papers (including their dissemination) were supported from the following institutional grants:

- Economic Aspects of EU and EMU Entry [Ekonomické aspekty vstupu do Evropské unie a Evropské měnové unie], No. AVOZ70850503, (2005-2010);

- Economic Impact of European Integration on the Czech Republic [Ekonomické dopady evropské integrace na ČR], No. MSM0021620846, (2005-2011);

Specific research support and/or other grants the researchers/publications benefited from are acknowledged at the beginning of the Paper.

(c) Byeongju Jeong, 2005

All rights reserved. No part of this publication may be reproduced, stored in a retrieval system or transmitted in any form or by any means, electronic, mechanical or photocopying, recording, or otherwise without the prior permission of the publisher.

Published by

Charles University in Prague, Center for Economic Research and Graduate Education (CERGE) and

Economics Institute (EI), Academy of Sciences of the Czech Republic

CERGE-El, Politických vězñu 7, 11121 Prague 1, tel.: +420 224005 153, Czech Republic.

Printed by CERGE-EI, Prague

Subscription: CERGE-El homepage: http://www.cerge-ei.cz

Editors: Directors of CERGE and EI

Managing editors: Deputy Directors for Research of CERGE and EI

ISSN 1211-3298

ISBN 80-7343-049-5 (Univerzita Karlova v Praze, CERGE)

ISBN 80-7344-038-5 (Národohospodářský ústav AV ČR, Praha) 
CERGE-EI

P.O.BOX 882

Politických vězňů 7

11121 Praha 1

Czech Republic http://www.cerge-ei.cz 